\title{
The effect of technological innovation capabilities on companies' innovation and marketing performance: A field study on Technopark companies in Turkey
}

\author{
Erkan Bil ${ }^{1}$ \\ (1D) \\ Erkan Özdemir ${ }^{2}$ \\ 1 Assit. Prof. Dr., Çanakkale Onsekiz Mart University, Faculty of Political Sciences, Department of Business Administration, Çanakkale, TURKEY, e-mail: erkanbil@comu.edu.tr \\ 2 Prof. Dr., Bursa Uludag University, Faculty of Economics and Administrative Sciences, Department of Business Administration, Bursa, TURKEY, e-mail: eozdemir@uludag.edu.tr
}

\section{Abstract}

Purpose - The purpose of this study is to evaluate the effects of the technological innovation capabilities of companies carrying out $R \mathcal{E D}$ and innovation activities on product performance and marketing performance.

Methodology - The main population of this study comprises a total of 4916 companies that carry out their activities within the body of 56 Technoparks in Turkey on April 2018. IBM SPSS 23 and IBM AMOS 23 package programs were used in the analysis. In the study, explanatory factor analysis, confirmatory factor analysis, and Structural Equation Modeling (SEM) analysis were performed to test the relationships in the proposed research model, respectively.

Findings - As a result of the Structural Equation Modeling analysis, it was found that RED capability has significant and positive effects on product performance and marketing performance over product performance; and the learning capability, marketing capability, and finally product performance directly on marketing performance.

Originality/value - The main contribution of this study to the literature is that it not only explains the effects of some types of innovation on business performance but also deals with the relationship between innovation capabilities and business performance of companies in a more specific approach and reveals the effects of technological innovation capabilities on both product and marketing performance.

Keywords: innovation, technological innovation capabilities, product performance, marketing performance, technopark company Jel codes: M30, M31, M39

\section{INTRODUCTION}

Nowadays, in an environment where international competition is increasing with the effects of globalization, it is difficult to make a difference in the market, companies need continuous change and renewal to gain a competitive advantage and achieve sustainable success. In this period when consumption habits change rapidly, the number of substitute products increases, and the life span of products decreases, innovation activities become one of the most important sources of competitiveness of companies. With innovation activities, companies can gain benefits such as developing products and services that can create different value in the market, and attracting the attention of the consumers (Song et al., 2007; Muthoni, 2017; Moen et al., 2018).
Bu derginin içeriŏi Creative Commons Attribution-NonCommercial 4.0 Uluslararası Lisansı altında lisanslanmıştır.

Content of this journal is licensed under a Creative Common Attribution-NonCommercial 4.0 International License. 
Resource-based view suggests that competitive advantage and therefore performance depends on the resource possibilities of the company (Hooley \& Greenley, 2005). According to the approach, business resources alone may not be sufficient. Companies that can combine resources with capabilities and use them efficiently will be able to provide a superior competitive advantage. Therefore the capability of companies to maintain their innovation activities effectively and create more value, compared to the companies they compete with is not only dependent on the physical resources they have. Companies that incorporate their unique features together with physical resources while using their rare and hard-to-imitate capabilities effectively and also efficiently can gain a competitive advantage. At this point, it is very important for companies to have technological innovation capabilities in innovation activities.

Technological capabilities include all of the existing production processes, technology, new product development, production and abilities within the organization. These capabilities become effective depending on the technological changes in the sector, the state of the market, competitors and opportunities (Song et al., 2007). Therefore, these capabilities also require awareness of threats and opportunities (Wang et al., 2014). Successful technological innovation is not only dependent on technological capacity, it requires other innovation capabilities in the fields of production, marketing, organization, strategy planning, learning and resource allocation (Romijn \& Albaladejo, 2002).

The purpose of this study is to investigate the effects of the technological innovation capabilities of companies carrying out R\&D and innovation activities on product performance and marketing performance within the scope of the proposed research model. Literature studies have shown that (Del Montea \& Papagni, 2003; Vaccaro et al., 2010; Alam et al., 2013; Ribau et al., 2017; Zhang et al., 2019; Chen et al., 2020) the relations between innovation capabilities and performance of the companies are carried out in different sectors and countries. However, there are few studies evaluating business capabilities in terms of technological innovation capabilities (Chiesa et al., 1996; Guan \& Ma, 2003; Wang et al., 2008; Yam et al., 2010; Yu et al., 2017; Wang \& Zhang, 2018; Zastempowski et al., 2020). The most significant contribution of this study to the literature is to reveal the effects of technological innovation capabilities on both product and marketing performance by addressing the relationship between technological innovation capabilities and the business performance of companies in a more specific dimension.

This study consists of six parts. Firstly, the technological innovation capabilities are evaluated. Secondly, the literature on the relationship between technological capability types and product and marketing per- formance was examined and research hypotheses are developed. The research method is expounded in the methodology section. Thereafter, the research data were analyzed with explanatory factor analysis, confirmatory factor analysis and the Structural Equation Modeling analysis. In the conclusion part, the contributions of the study are emphasized by comparing with the literature and present suggestions for researchers and practical life-oriented perspectives.

\section{LITERATURE REVIEW}

\subsection{Technological Innovation Capabilities}

In the last quarter of the century, technological innovation capabilities have attracted the attention of many researchers (Chiesa et al., 1996; Panda and Ramanathan, 1996; Guan and Ma, 2003; Yam et al., 2004; Guan et al., 2006; Deng and Wang, 2007; Wang et al., (2008; Yam et al., 2010; Shan \& Jolly, 2010; Ashtianipour \& Zandhessami, 2015; Aljanabi, 2018; Yao et al., 2020). While some researchers (Yam et al., 2004) examine technological innovation capabilities in the context of their relationships with other important business elements such as organizational, marketing, capital funds, production, strategic planning and resource allocation; some researchers (Guan et al., 2006; Wang et al., 2008) examined technological innovation capabilities by dividing them into dimensions such as learning capability, R\&D capability, production capability, marketing capability, resource utilization capability, organizational capability and strategic capabilities.

In this study, technological innovation capabilities are evaluated under five dimensions which are; $R \& D$ capability, learning capability, strategic planning capability, innovation capability and marketing capability.

\subsubsection{R\&D Capability}

R\&D activities are a highly important variable used in defining the technological capabilities of a country or a company. These activities play an effective role in both developing new knowledge and adapting this information to society (Cohenn, 1989). R\&D capabilities include skills that help an organization develop new technical knowledge, combine them with existing technology, and design superior products and services (Krasnikov \& Jayachandran, 2008).

\subsubsection{Learning Capability}

Technological innovation can be related to learning process (Cohen \& Levinthal, 1989; Garvin, 1993; Hitt et al., 2000). In this context, learning capability can be explained as the capability to develop or acquire new knowledge-based resources and skills that a business needs to present new products. Companies can make technological capabilities that aim to provide a com- 
petitive advantage to businesses more effectively through their learning capability (Hull \& Covin, 2010).

\subsubsection{Strategic Planning Capability}

Strategic planning capability is defined as the capability of a company to identify its strengths and weaknesses as well as opportunities and threats, and to create plans in line with corporate vision and missions (Lau et al., 2010). In this context, strategic planning capability can be seen as one of the capabilities of the organization's internal processes. McKelvie and Davidsson (2009) expressed organizational capabilities as the capability to organize and coordinate resources in order to achieve the company's goals. Each business develops its own talent type and level according to the competitive market, past responsibilities, and anticipated needs. Within this context it can be stated that a company has the resources and abilities which can demonstrate its capability in the most appropriate way in order to gain competitive advantage and as a result, it can achieve success (Song et al., 2007).

\subsubsection{Innovation Capability}

There are different approaches to the definition of innovation capability in the literature. Romijn and Albaladejo (2002) defined innovation capability as "the knowledge and capabilities required to effectively absorb and develop existing technologies and create new ones". Lawson and Samson (2001) claim that innovation capability is an important factor in the development of innovation outputs and emerges at different stages of the innovation process. The authors also argued that an organization's innovation capability "reflects the capability to continually transform knowledge and ideas into new products, processes and systems."

\subsubsection{Marketing Capability}

Wernerfelt (1984) and Barney (1991) express marketing capability as the capability of a company to use its resources by gaining the competitive advantage. Vorhies (1998) expresses marketing capability as integral processes designed to apply the collective knowledge, skills and resources of the company to the market-related needs of the company. According to the author, marketing capability enables the business to add value by adapting its goods and services to market conditions, taking advantage of market opportunities and meeting competitive threats.

\section{RESEARCH MODEL AND HYPOTHESES DEVELOPMENT}

In this study, technological capability types of companies are associated with product and marketing performance factors. As it is known, the competitive advantage of a company stems from its new product development capacity and efficiency (Lawless \& Fisher, 1990; Guan, 2002). New products can be considered as a result of the innovative activities of the company. Therefore, new products developed as a result of innovative applications of the companies will be able to provide a competitive advantage in the market by creating superior customer value (Han et al., 1998). Considering the extant literature, the performance dimensions of companies related to innovativeness and product development are associated with indicators such as the number of patents (Chen \& Yang, 2009), the number of new products introduced to the market (Hull \& Covin, 2010), patents and intellectual property (Zhao et al., 2005).

Performance for businesses can be defined as the total effort of the company to reach the targeted point or purpose (Karaman, 2009). Innovation is also a factor that has a significant positive effect on performance, emerging as a strong determinant of marketing performance (Weerawardena, 2003; Hult et al., 2004). Performance measurement, on the other hand, can be explained as data collection, analysis and reporting by continuously analyzing the results obtained with the products or services produced (Ege \& Şener, 2013). Companies with innovation capability supported by market orientation are more successful in responding to their environment faster and making innovations that provide high performance and competitive advantage (Gatignon \& Xuereb, 1997).

Research hypotheses are presented by considering the relationship between technological capability types and performance in the first five subtitles below, and the relationship between product performance and marketing performance in the sixth subtitle.

\subsection{R\&D Capability and Performance Relationship}

R\&D capability is expressed as the capability of a company to integrate its R\&D strategy, project implementations and R\&D expenditures (Lau et al., 2010). The output of the R\&D efforts of the company is generally estimated by the number of patents or new products (Jaffe, 1989; Acs et al., 1992) developed as a result of innovation activities. Studies have directly focused on the relationship between $R \& D$ expenditures and company innovation activities and found that there is a positive relationship between these two variables (Dasgupta, 1985; Hopenhayn, 1992). Caloghirou et al. (2004) argue that the higher the R\&D efforts and training within a business, the more innovation the company will create and use. McMillan et al. (2003), on the other hand, analyzed the American pharmaceutical industry and stated that R\&D spending is a marker of new products developed.

On the other hand, according to the literature, there are also studies investigating the relationship between 
R\&D activities and business performance. In this context, researchers found that $R \& D$ expenditures positively affect business performance and growth (Karacaer et al., 2009; Falk, 2012; Demirel \& Mazzucato, 2012; VanderPal, 2015; Guo et al., 2018; Guo et al., 2020), increasing net sales (Garcia-Manjon \& Romero-Merino, 2012) and market value (Nord, 2011). Thus, the following hypotheses are proposed:

$H_{1}: R E D$ capability has a positive effect on product performance.

$H_{4}: R E D$ capability has a positive effect on marketing performance.

\subsection{Learning Capability and Performance Relations- hip}

Learning should be considered as an important element for the company to access, acquire and develop new knowledge and as one of the most valuable assets that provide sustainable competitive advantage (Caloghirou et al., 2004). Learning capability is defined as the capability to bring out effective ideas through certain managerial initiatives (Yeung et al., 1999) and the capability of an organization to take these lessons into the future by taking lessons from its experiences (Ashkenas et al., 1995).

According to the literature, the studies show that there is a positive relationship between organizational learning and business performance (Baker \& Sinkula, 1999; Goh \& Ryan, 2002; Bontis et al., 2002; Gomes \& Wojahn, 2017; Hindasah \& Nuryakın, 2020). Baker and Sinkula (1999) found that organizational learning has a direct effect on performance. Bontis et al. (2002) obtained findings show that there is a positive relationship between organizational learning and performance by using the learning culture scale. Similarly, Hindasah and Nuryakin (2020) found that organizational learning significantly affects financial performance. In an intensely competitive environment, organizational learning capability is seen as a value-adding factor that determines the continuity of the stakeholder's relationships based on creating added value. Therefore the stronger the learning capability, the higher the number of stakeholders and the maximum added value will be. As a result of this, better performance will come out (Ting, 2012). Thereby the following hypotheses are proposed:

$\mathrm{H}_{2}$ : Learning capability has a positive effect on the product performance.

$\boldsymbol{H}_{5}$ : Learning capability has a positive effect on marketing performance.

\subsection{Strategic Planning Capability and Performance Relationship}

The capability of strategic planning is explained as the capability of a company to be defining its strengths and weaknesses while identifying opportunities and threats and creating plans in line with corporate vision and missions (Lau et al., 2010). Strategic planning capability can be seen as one of the capabilities of the organization's internal processes. McKelvie and Davidsson (2009) expressed organizational capabilities as the capability to organize and coordinate resources in order to achieve the company's goals.

Montes et al. (2005) stated that organizational capabilities affect the performance of the company; those factors such as market share, profitability, costs, sales revenues and customer satisfaction significantly affect sustainable competition. Cooper (1984) also stated in his study that there is a relationship between corporate strategy and innovation performance and that well-defined corporate strategies and planning related to new technology are positively associated with the rate of innovation (Rothwell, 1992; Swan and Newell, 1995; Lau et al., 2010). In addition, there are studies (Ojha et al., 2020; AlQershi, 2021) which show that strategic planning capability has an impact on business performance. Accordingly, the following hypothesis is proposed:

$\boldsymbol{H}_{\mathbf{g}}$ : Strategic planning capability has a positive effect on marketing performance.

\subsection{Innovation Capability and Performance Relati- onship}

In the competitive environment among companies, which has become more dynamic due to the rapid socio-economic changes, innovation activities have become the main source of a company to establish a competitive advantage against its competitors (Erdem et al., 2011). Companies that adopt innovation activities tend to perform better than their non-innovative competitors (Vaccaro et al., 2010; Forsman, 2011; Alam, 2013). Innovation capabilities arise from individual competencies, knowledge acquired in the past and attempts to diversify knowledge production tools (Cohen \& Levinthal, 1990; Lee et al., 2012). Technological innovation capabilities are the capability to carry out any relevant activity within the company, including the capability to develop new products and processes, and the capability to effectively operate its facilities (Teece et al., 1997).

Considering the literature, it is observed that R\&D investments are positively associated with the growth of companies (Del Montea \& Papagni, 2003) and the increase in market values (Bae \& Kim, 2003) and that innovation capabilities positively affect company performance (Guen \& Ma, 2003). 2003; Jimenez and Valle, 
2011; Alam et al., 2013; Ngumi, 2014; Ali et al., 2020; Zimmermann et al., 2020). On the other hand, Vaccaro et al. (2010) states that the effective use of information management tools positively affects new product performance, speed entering into the market and business performance. Thus, the following hypotheses are proposed:

$\mathrm{H}_{3}$ : Innovation capability has a positive effect on product performance.

$\boldsymbol{H}_{6}:$ Innovation capability has a positive effect on marketing performance.

\subsection{Marketing Capability and Performance Relati- onship}

Market orientation, which is an important factor that makes it easier for companies to realize their inherent capabilities and supports their innovation capabilities, directly affects new product decisions (Atuahene-Gima, 1996). Companies with marketing capabilities supported by innovation capabilities are more successful in responding faster to changes and developments, showing high performance and making innovations that provide competitive advantage (Gatignon \& Xuereb, 1997). The relationship between marketing capabilities and business performance has been studied by many marketing researchers (Hooley et al., 1999; Vorhies \& Harker, 2000; Tsai \& Shih, 2004; Krasnikov \& Jayachandran, 2008; Azizi et al., 2009; Fang \& Zou, 2009; Eng and Jones, 2009; Ramaswami et al., 2009; Morgan et al., 2009a, 2009b; Ros et al., 2010; Jaakkola et al., 2010; Nath et al., 2010; Chahal and Kaur, 2013; Ren et al., 2015; Ferreira et al., 2018; Davcik et al., 2020; Acikdilli et al., 2020; Mehta and Ali, 2020; Novita et al., 2020).

Hooley et al. (1999) consider marketing culture as marketing capabilities that are more strongly associated with business performance. They argued that it creates customer value, is difficult to imitate, and results in the creation of sustainable competitive advantage. Similarly, it is observed that marketing capabilities create a sustainable competitive advantage for the companies and thus provide superior performance (Tsai \& Shih, 2004; Morgan et al., 2009a; Murray et al., 2011; Ferreira et al., 2018), by increasing company profitability (Vorhies and Harker, 2000) positively affect growth (Morgan et al., 2009b), and positively correlate with marketing performance (Hooley et al., 2005) and overall business performance (Azizi et al., 2009; Eng and Jones, 2009; Nath et al., 2010; Ros et al., 2010; Novita et al., 2020). Thereby, it is hypothesized that:

$\boldsymbol{H}_{7}$ : Marketing capability has a positive effect on marketing performance.

\subsection{Product Performance and Marketing Performan- ce Relationship}

Innovation can be seen as a factor that has a significantly positive effect on performance and emerges as a strong determinant of marketing performance (Weerawardena, 2003; Hult et al., 2004). In this context, although many studies are examining the relationship between innovation and performance (Calantone et al., 2002; Xin et al., 2010; Tatar, 2010; Ehie \& Olibe, 2010; Bigliardi, 2013; Muhammed et al., 2014; Jajja et al., 2017; Exposito and Sanchis-Llopis, 2018; Christa \& Kristinae, 2021), however, there is a limited number of studies that explain the positive relationship between innovation performance and marketing performance (Cheng \& Krumwiede, 2010; Gunday et al., 2011; Stock \& Reiferscheid, 2014; Gök \& Peker, 2017; Kristinae et al., 2020; Nurjaya et al., 2021).

On the other hand, the performance dimensions of companies related to innovation and product development are associated with the number of patents (Romijn \& Albaladejo, 2002; Chen \& Yang, 2009), R\&D projects (Elmquist \& Le Masson, 2009), the number of new products introduced to the market (Hull \& Covin, 2010), new materials, new product functions and new design (Nassimbeni, 2001), patent and R\&D intensity (Sher \& Yang, 2005); patents and intellectual property generated (Zhao et al., 2005).

Xin et al. (2010) determined that technologically innovative products have a statistically significant and positive effect on business performance. In another similar study, Artz et al. (2010) examined the effect of patents and innovative products on business performance in different sectors of the USA and Canada and concluded that innovative products have a significant impact on business performance. Additionally, Stock and Reiferscheid (2014) found that product innovation activities supported by R\&D power in an intensely competitive environment have positive effects on the marketing performance of companies. Accordingly, the following hypothesis is proposed:

$\boldsymbol{H}_{8}$ : Product performance has a positive effect on marketing performance.

As a result of the literature review, the research model shown in Figure 1 below is developed: 
Figure 1: Research Model of the Study

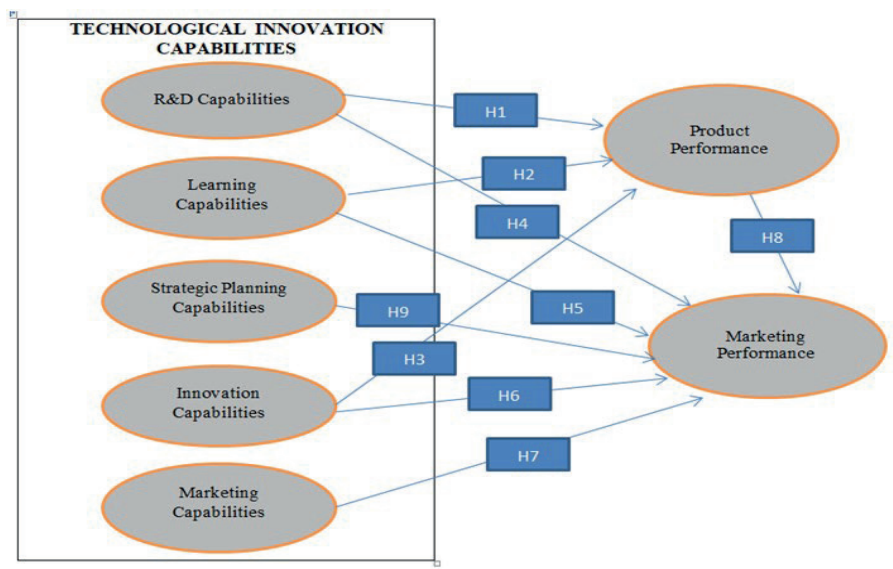

The research model developed in the light of the literature review within the scope of the study, the effects of business capabilities, which are considered as technological innovation capabilities, on product performance and marketing performance are investigated.

\section{METHODOLOGY}

The purpose of this study is to investigate the effects of the technological innovation capabilities of companies carrying out R\&D and innovation activities on product performance and marketing performance. The main population of this research comprises a total of 4916 companies which carry out their activities within the body of 56 Technoparks that have started their operations in Turkey according to the data of the Ministry of Industry and Technology of the Republic of Turkey in April 2018. Within the scope of the study, no sampling study was conducted and it was tried to reach the entire population. However, the minimum sample size that can represent the main population was calculated as 357 at $95 \%$ confidence interval according to the formula used (Bal, 2001). There are two parts in the questionnaire form: categorical questions and questions based on the Likert scale. The scales used in the evaluation of business capabilities and marketing performance are previously accepted scales in the literature. The questionnaire items were scored on a five-point Likert scale, ranging from "strongly disagree" to "strongly agree". There are 56 items in total in these scales generated by using the literature.

To test the conceptual model and hypothesis of the study, an online survey method was used to collect data. Before the data collection, the pilot test was conducted with 30 companies in order to test the understandability of the items in the questionnaire form and to identify possible deficiencies. As a result of the pilot study, the questionnaire application continued without removing any item from the questionnaire form. The pilot and main surveys were conducted between 04 - 19.10.2018. A total of 402 questionnaires were collected and 391 useful questionnaires were included into the analysis.

The scales used in this research were structured by making a wide literature review in relation to innovation capabilities, product performance and marketing performance based on the studies conducted by Yam et al. (2004), Chen and Huang (2009), Merrilees et al. (2010). In this context, the "Technological Innovation Capabilities Scale" developed by Yam et al. (2004) was used for measuring the technological innovation capabilities of the companies in the research. The scale developed by Chen and Huang in 2009 was used for measuring the innovation capability of the companies and the scale developed by Merrilees et al. (2010) was used for measuring the marketing performance of the companies.

On the other hand, in order to evaluate product performance of the companies, four indicators used by the Ministry of Industry and Technology of the Republic of Turkey (2018) to evaluate outcomes associated with intellectual and industrial property rights of companies operating in the Technopark (the patents, utility model registration, industrial design registration and software copyright numbers developed by the company in the last three years) were developed by the authors as a statement of scale.

\section{ANALYSIS RESULTS}

\subsection{Findings Regarding Participants}

When the data on the demographic characteristics of the attendants participating in the research are investigated, the study shows that $315(80.6 \%)$ of the participants were men and 76 (19.1\%) were women. Looking at their age breakdown, it is seen that 187 (47.8\%) participants are concentrated in the 25-34 age range, followed by 109 (27.9\%) participants in the 35-44 age range. After examining the educational status of the attendants, it is seen that $54.5 \%$ are undergraduates and $24.8 \%$ are graduates. Considering the working time of the participants, it is seen that employees between 
1-3 years make up 185 (47.3\%) participants and almost half of the total number of participants, followed by 75 $(19.2 \%)$ participants who work less than one year. Regarding the positions of the attendants in the businesses are considered, the study shows that 131 (33.5\%) of the participants are R\&D personnel and 107 (27.4\%) are company owners.

In the light of the information about the characteristics of the companies participating in the research is investigated, it is seen that $81.8 \%$ of the companies have domestic and $10 \%$ foreign shareholding structures. Given "the legal status of the companies, it has been determined that companies that are Limited Company $(58.3 \%)$ and Joint Stock Company $(33.8 \%)$ are in the majority. In the view of the positions of the employees in the company being investigated, it is seen that there are more R\&D personnel (33.5\%) and company owners $(27.4 \%)$. The proportion of companies with less than 10 employees is $56.8 \%$, while the rate of companies with more than 200 employees is $1.5 \%$. Taking into account the distribution of the sectors in which the companies operate is put under investigation, respectively, it is seen that software $(26.1 \%)$, computer and communication technologies (23\%) and electronics $(13 \%)$ sectors are concentrated. It is known that $42.2 \%$ of the company's export, while $57.8 \%$ do not. The majority of the companies (48.1\%) have been operating in the Technopark for 1-3 years, while $22.3 \%$ have been operating in the technopark for less than a year. This situation can be evaluated as a result of companies presenting projects and taking part in technoparks.

\subsection{Reliability Analysis of the Scale and Results Re- garding Normal Distribution}

The reliability of the scale consisting of 56 expressions used in the study was measured with the Cronbach Alpha value. The Cronbach's Alpha value of the expressions in the scale was obtained as 0.973 . This result, which is above the value of 0.70 accepted in the literature, shows that the scale used in the study is reliable. In addition to scale reliability, kurtosis and skewness values of the data were examined in the study. It is stated that kurtosis and skewness values should be between -1.5 and +1.5 in the literature (Tabachnick \& Fidell, 2007). The values obtained as a result of the analysis were found within these limits, and it was observed that the data had a normal distribution.

\subsection{Explanatory Factor Analysis Results}

In this part of the study, 56 variables were subjected to exploratory factor analysis. Before determining the sub-dimensions, the reliability coefficient of the items included in the factor analysis was calculated as 0.973 (Cronbach's Alpha). This value obtained indicates a very high-reliability result.
It is seen that the chi-square ( $22(1176)=155595,15 ; \mathrm{p}$ $<0.01)$ value obtained according to Bartlett Sphericity test result is significant. The KMO (Kaiser-Meyer-Olkin) coefficient was found to be 0.951 , this result being close to 1 indicates that the data are suitable for factor analysis and the sample size of the study is sufficient. According to the Explanatory Factor Analysis results, it was determined 8 factors and these factors explained $70 \%$ of the total variance. The maximum variance rotation technique (varimax rotation), which is one of the orthogonal rotation techniques and maximizes the amount of variance, was used for the determined 8 factors. Expressions with a factor load of 0.50 and above were included in the analysis. 7 expressions with a factor load of less than 0.50 were excluded from the analysis. As a result, the first factor consists of 12; the 2nd factor consists of 9; 3rd factor consists of 6 ; 4 th factor consists of 5 ; 5 th factor consists of 5 ; 6 th factor consists of 4; 7th factor consists of 4 and the 8th factor consists of 4 variables. According to the results, the first factor is determined as R\&D Capability, the second factor as Learning Capability, the third factor as Innovation Capability, the fourth factor as Internal Marketing Capability, the fifth factor as Strategic Planning Capability, the sixth factor as Product Performance, the seventh factor as Marketing Performance, and the eighth factor as External Marketing Capability. When the contribution of each factor to the total variance is examined, the explanation rate of $R \& D$ capability, which is the first factor, is the highest with $42 \%$, followed by learning capability and innovation capability.

\subsection{Confirmatory Factor Analysis Results}

In order to test the measurement and construct validity of the scales used for the research model, the measurement model was first developed and then this model was studied by confirmatory factor analysis. The measurement model was subjected to confirmatory factor analysis with respect to two different approaches. Firstly, since Structural Equation Modeling was used in the study, the adequacy of the measurement model developed was controlled by examining the goodness of fit values. Secondly, the adequacy of the measurement model was investigated with convergent and discrimination validity. The measurement model was developed using the expression elimination method as suggested in the research model. In order to obtain acceptable goodness of fit values, 22 statements were removed from the analysis through the measurement model consisting of 49 statements.

After the statement elimination process; 8 statements from the R\&D capability scale consisting of 12 statements; 5 statements from the learning capability scale consisting of 9 statements; 2 statements from the strategic planning capability scale consisting of 5 statements; 3 statements from the innovation ca- 
pability scale consisting of 6 statements; 4 statements consisting of 9 statements, were excluded from the marketing capability scale. After the expression screening modification, the measurement model consisted of 27 expressions.

In this study, GFI, AGFI, CFI, NFI, RMSEA, $R M R$ values and $X 2$ / df ratio were used as a goodness of fit indices for the measurement model and later Structural Equation Modeling analysis. Table 1 shows the goodness of fit values of the measurement model obtained before and after expression elimination. When Table 3 is examined, the values obtained after the modification of expression screening are above the limits generally accepted in the literature (Baumgartner \& Homburg, 1996; Iacobucci, 2010; Schermelleh-Engel et al., 2003; Weston \& Gore, 2006) and the values are acceptable and they appear to have a good fit.

The results of the confirmatory factor analysis of the proposed measurement model are shown in Table 2. The method suggested by Fornell and Larcker (1981) was used to test the convergence validity. In order to confirm the convergent validity of the scale used according to this method, the Average Variance Extracted (AVE) values of the variables are above 0.50; Composite Reliability (CR) values should be above 0.60 (acceptable) (if it is above 0.70 is a recommended good value) (Hair et al., 2014). Bagozzi and Yi (1988) indicate that the composite reliability value of above 0.60 is sufficient. Composite reliability $(\mathrm{CR})$ indicates to what extent the observed variables represent the latent structure (Fornell \& Larcker, 1981). The AVE value is found by dividing the sum of the squares of the covariances (loads) of the expressions in each scale by the number of expressions (Eskioğlu, 2017).

As seen in Table 2, the reliability values of each scale are higher than 0.70 accepted in the literature. These values show that the reliability of the scale is sufficient. In addition to the reliability values of each scale, the Cronbach's Alpha value calculated for all 27 statements in the scales was calculated as 0.934 . This value shows that the total scale reliability is sufficient as well. As a result of the analysis, the Cronbach Alpha coefficients of the structures in the research are between 0.809 and 0.912 ; internal consistency reliability was achieved by realizing the CR coefficients between 0.817 and 0.905 .
Table 1. Measurement Model Results (Before and After Expression Screening)

\begin{tabular}{|l|l|l|l|l|}
\hline \multirow{2}{*}{$\begin{array}{l}\text { Fit } \\
\text { Criteria }\end{array}$} & \multicolumn{2}{|l|}{$\begin{array}{l}\text { Values Accepted in the } \\
\text { Literature }\end{array}$} & $\begin{array}{l}\text { Measurement Model Results } \\
\text { Values }\end{array}$ & $\begin{array}{l}\text { After Expression } \\
\text { Vlimination } \\
\text { Modification }\end{array}$ \\
\hline $\boldsymbol{\chi 2} / \mathbf{d f}$ & $2 \geq \chi 2 / \mathrm{df} \geq 3$ & $0 \geq \chi 2 / \mathrm{df} \geq 2$ & 3.042 & 1.947 \\
\hline CFI & $.95 \geq \mathrm{CFI} \geq .97$ & $\begin{array}{l}.97 \geq \mathrm{CFI} \geq \\
1.00\end{array}$ & 0.851 & 0.958 \\
\hline GFI & $.90 \geq \mathrm{GFI} \geq .95$ & $\begin{array}{l}.95 \geq \mathrm{GFI} \geq 97 \\
\text { Mefore }\end{array}$ & 0.739 & 0.900 \\
\hline AGFI & $.85 \geq \mathrm{AGFI} \geq .90$ & $\begin{array}{l}.90 \geq \mathrm{AGFI} \geq \\
1.00\end{array}$ & 0.710 & 0.874 \\
\hline NFI & $.90 \geq \mathrm{NFI} \geq .95$ & $\begin{array}{l}.95 \geq \mathrm{NFI} \geq \\
1.00\end{array}$ & 0.794 & 0.918 \\
\hline RMR & $0.5 \geq \mathrm{RMR} \geq .10$ & $0 \geq \mathrm{RMR} \geq .05$ & 0.054 & 0.043 \\
\hline RMSEA & $\begin{array}{l}.05 \geq \mathrm{RMSEA} \geq \\
.08\end{array}$ & $\begin{array}{l}0 \geq \mathrm{RMSEA} \geq \\
.05\end{array}$ & 0.072 & 0.049 \\
\hline
\end{tabular}

Table 2. Confirmatory Factor Analysis Results

\begin{tabular}{|c|c|c|c|c|c|c|c|}
\hline $\begin{array}{l}\text { Scale and } \\
\text { number of } \\
\text { expression } \\
\text { s }\end{array}$ & $\begin{array}{c}\text { Codes } \\
\text { of Items }\end{array}$ & $\begin{array}{l}\text { Fact. } \\
\text { Load. }\end{array}$ & Avg. & $\begin{array}{l}\text { Std. } \\
\text { Dev. }\end{array}$ & $\begin{array}{c}\text { Cronbach's } \\
\text { Alfa }\end{array}$ & $\begin{array}{c}\text { CR } \\
\text { Value }\end{array}$ & $\begin{array}{c}\text { AVE } \\
\text { Value }\end{array}$ \\
\hline \multirow{4}{*}{$\begin{array}{l}\text { R\&D } \\
\text { Capability } \\
\text { (4) }\end{array}$} & $\begin{array}{l}\text { ARGEY } \\
9\end{array}$ & .785 & 3.99 & 0.979 & \multirow{4}{*}{0.879} & \multirow{4}{*}{0.879} & \multirow{4}{*}{0.646} \\
\hline & $\begin{array}{l}\text { ARGEY } \\
6\end{array}$ & .786 & 4.26 & 0.939 & & & \\
\hline & $\begin{array}{l}\text { ARGEY } \\
4\end{array}$ & .851 & 4.06 & 0.933 & & & \\
\hline & $\begin{array}{l}\text { ARGEY } \\
3\end{array}$ & .791 & 4.05 & 0.986 & & & \\
\hline \multirow{4}{*}{$\begin{array}{l}\text { Learning } \\
\text { Capability } \\
\text { (4) }\end{array}$} & OY8 & .761 & 4.32 & 0.896 & \multirow{4}{*}{0.837} & \multirow{4}{*}{0.838} & \multirow{4}{*}{0.565} \\
\hline & OY7 & .734 & 4.02 & 0.942 & & & \\
\hline & OY4 & .780 & 4.15 & 0.857 & & & \\
\hline & OY1 & .730 & 4.16 & 0.933 & & & \\
\hline \multirow{3}{*}{$\begin{array}{l}\text { Strategic } \\
\text { Planning } \\
\text { Capability } \\
\text { (3) }\end{array}$} & SPY3 & .771 & 3.98 & 0.894 & \multirow{3}{*}{0.809} & \multirow{3}{*}{0.817} & \multirow{3}{*}{0.600} \\
\hline & SPY2 & .851 & 4.06 & 0.885 & & & \\
\hline & SPY1 & .694 & 3.82 & 1.009 & & & \\
\hline \multirow{3}{*}{$\begin{array}{l}\text { Innovation } \\
\text { Capability } \\
\text { (3) }\end{array}$} & Y4 & .847 & 3.94 & 0.936 & \multirow{3}{*}{0.901} & \multirow{3}{*}{0,900} & \multirow{3}{*}{0.751} \\
\hline & Y3 & .883 & 4.05 & 0.916 & & & \\
\hline & Y2 & .869 & 4.08 & 0.894 & & & \\
\hline \multirow{2}{*}{$\begin{array}{l}\text { Marketing } \\
\text { Capability } \\
\text { (Internal) } \\
(2)\end{array}$} & PY4 & .944 & 3.72 & 1.091 & \multirow[b]{2}{*}{0.912} & \multirow[b]{2}{*}{0.904} & \multirow[b]{2}{*}{0.826} \\
\hline & PY3 & .872 & 3.77 & 1.067 & & & \\
\hline \multirow{3}{*}{$\begin{array}{l}\text { Marketing } \\
\text { Capability } \\
\text { (External) } \\
\text { (3) }\end{array}$} & PY9 & .789 & 4.28 & 0.818 & \multirow{3}{*}{0.825} & \multirow{3}{*}{0.838} & \multirow{3}{*}{0.633} \\
\hline & PY8 & .802 & 4.18 & 0.925 & & & \\
\hline & PY7 & .796 & 4.12 & 0.963 & & & \\
\hline \multirow{4}{*}{$\begin{array}{l}\text { Product } \\
\text { Performanc } \\
\text { e (4) }\end{array}$} & UP4 & .721 & 1.60 & 0.871 & \multirow{4}{*}{0.899} & \multirow{4}{*}{0.905} & \multirow{4}{*}{0.706} \\
\hline & UP3 & .883 & 1.59 & 0.869 & & & \\
\hline & UP2 & .946 & 1.54 & 0.770 & & & \\
\hline & UP1 & .793 & 1.62 & 0.868 & & & \\
\hline \multirow{4}{*}{$\begin{array}{l}\text { Marketing } \\
\text { Performanc } \\
\text { e (4) }\end{array}$} & PP4 & .738 & 3.78 & 0.964 & \multirow{3}{*}{0.829} & \multirow{3}{*}{0.839} & \\
\hline & PP3 & .628 & 3.60 & 1.111 & & & 0.568 \\
\hline & PP2 & .802 & 3.84 & 0.916 & & & \\
\hline & PP1 & .831 & 3.60 & 0.992 & & & \\
\hline
\end{tabular}


Factor loadings are between 0.628 and 0.946 ; since the AVE values are between 0.565 and 0.826 , it is observed that the composite validity is provided. In summary, the observed variables explain the scale sufficiently and consistently.

At the last stage of the confirmatory factor analysis, the discrimination validity of the relevant scales was calculated. The method proposed by Fornell and Larcker (1981) was used to determine the validity of the discrimination. According to this method, the square root of the average variance extracted (AVE) value of a dimension must be greater than the correlation values of this dimension comparing to the other dimensions (Fornell \& Larcker, 1981). According to the results, it is seen that the dimensions in the proposed measurement model are separate structures and the discrimination validity is confirmed. Data on the validity of the discrimination are presented in Table 3.

It is seen that the average variance extracted value of each structure is higher than its correlation comparing to the other structures by considering Table 3. Consequently, the findings show that the proposed measurement model meets the reliability and validity conditions before the structural equation model and the data are suitable for structural analysis.

\subsection{Structural Equation Modeling Analysis Results}

Following the convenient results obtained from the proposed measurement model, the effect of technological innovation capabilities on product and marketing performance was tested with Structural Equation Modeling analysis using IBM AMOS 23 package program. Hypotheses regarding the effect of R\&D Capability, Learning Capability and Innovation Capability factors on product performance and R\&D Capability, Learning Capability, Innovation Capability, Marketing Capability, Product Performance and Strategic Planning Capability factors on marketing performance were tested at 0.05 significance level $(\mathrm{p}<0.05)$.

The goodness of fit values of the proposed structural model is shown together with the acceptable and good fit values in the literature in Table 4.

When the goodness of fit values in Table 4 are examined, it is seen that the proposed model has a good fit. In other words, the findings show that the proposed structural model is acceptable.

In the proposed structural equation model, R\&D capability, learning capability, strategic planning capability, innovation capability and marketing capability dimensions show exogenous latent variables, product

Table 3. Discrimination Validity Analysis Results

\begin{tabular}{|l|l|l|l|l|l|l|l|}
\hline Scale Dimensions & $\mathbf{1}$ & $\mathbf{2}$ & $\mathbf{3}$ & $\mathbf{4}$ & $\mathbf{5}$ & $\mathbf{6}$ & $\mathbf{7}$ \\
\hline R\&D Capability (1) & $\mathbf{0 . 8 0 3}$ & & & & & & \\
\hline Learning Capability (2) & $.726^{* *}$ & $\mathbf{0 . 7 5 1}$ & & & & & \\
\hline $\begin{array}{l}\text { Strategic Planning Capability } \\
(\mathbf{3})\end{array}$ & $.635^{* *}$ & $.602^{* *}$ & $\mathbf{0 . 7 7 4}$ & & & & \\
\hline Innovation Capability (4) & $.682^{* *}$ & $.682^{* *}$ & $.672^{* *}$ & $\mathbf{0 . 8 6 6}$ & & & \\
\hline Marketing Capability (5) & $.693^{* *}$ & $.607^{* *}$ & $.599^{* *}$ & $.662^{* *}$ & $\mathbf{0 . 9 3 3}$ & & \\
\hline Product Performance (6) & $.094^{* *}$ & .036 & .087 & $.038^{* *}$ & .092 & $\mathbf{0 . 9 5 1}$ & \\
\hline Marketing Performance (7) & $.406^{* *}$ & $.440^{* *}$ & $.432^{* *}$ & $.424^{* *}$ & $.506^{* *}$ & $.156^{* *}$ & $\mathbf{0 . 9 1 5}$ \\
\hline **. Correlation is significant at the 0.01 level (2-tailed). & & & & \\
\hline
\end{tabular}

Note: The correlation matrix between scales is given on the right side of the table. The diagonal elements of the correlation matrix show the square root of the AVE (bold values) and the non-diagonal elements show the correlation values between the scales.

Table 4. SEM Analysis Goodness of Fit Values

\begin{tabular}{|c|c|c|c|}
\hline \multirow[b]{2}{*}{ Fit Criteria } & \multicolumn{2}{|c|}{ Values Accepted in the Literature } & \multirow{2}{*}{$\begin{array}{l}\text { Results Obtained } \\
\text { After the Analyses }\end{array}$} \\
\hline & $\begin{array}{l}\text { Acceptable } \quad \text { Fit } \\
\text { Values }\end{array}$ & Good Fit Values & \\
\hline$\chi^{2 / d f}$ & $2 \geq \chi^{2 / \mathrm{df}} \geq 3$ & $0 \geq \chi 2 / \mathrm{df} \geq 2$ & 1.937 \\
\hline CFI & $.95 \geq \mathrm{CFI} \geq .97$ & $.97 \geq \mathrm{CFI} \geq 1.00$ & 0.958 \\
\hline GFI & $.90 \geq \mathrm{GFI} \geq .95$ & $.95 \geq \mathrm{GFI} \geq 97$ & 0.900 \\
\hline AGFI & $.85 \geq \mathrm{AGFI} \geq .90$ & $.90 \geq \mathrm{AGFI} \geq 1.00$ & 0.875 \\
\hline NFI & $.90 \geq \mathrm{NFI} \geq .95$ & $.95 \geq \mathrm{NFI} \geq 1.00$ & 0.918 \\
\hline RMR & $0.5 \geq \mathrm{RMR} \geq .10$ & $0 \geq \mathrm{RMR} \geq .05$ & 0.043 \\
\hline RMSEA & $.05 \geq \mathrm{RMSEA} \geq .08$ & $0 \geq \mathrm{RMSEA} \geq .05$ & 0.049 \\
\hline
\end{tabular}


performance and marketing performance dimensions show endogenous latent variables. Table 5 shows the results of the Structural Equation Modeling analysis.

When Table 5 is investigated; It was determined that R\&D capability has positive and significant effects on product performance $(=0.304 ; \mathrm{p}<0.05)$; learning capability on marketing performance $(=0.347 ; \mathrm{p}<0.05)$; marketing capability on marketing performance (= $1.042 ; \mathrm{p}<0.05)$; and product performance on marketing performance $(=0.109 ; p<0.05)$. As a result of these findings, the hypotheses numbered 1, 5, 7 and 8 of the research were supported.

The p-value of the H4 hypothesis that R\&D capability has a positive effect on marketing performance was calculated as 0.031 . Since this value is $p<0.05$, although there is a significant relationship between $R \& D$ capability and marketing performance, the direction of the effect is negative. Therefore, although the result of the analysis is a significant relationship, the H4 hypothesis is not supported because the direction of the effect is negative. In this context, R\&D capability has a significant but negative effect on product performance.
On the other hand, no positive and significant effect was found for learning capability on product performance $(=-0.172 ; \mathrm{p}>0.05)$; innovation capability on product performance $(=-0,062 ; p>0.05)$ and marketing performance $(=-0,259 ; p>0.05)$ and strategic planning capability on marketing performance $(=-0.172$; $\mathrm{p}>$ $0.05)$. As a consequence, the hypotheses $2,3,6$ and 9 of the research were not supported.

\section{DISCUSSION AND CONCLUSION}

Innovation activities can improve business performance in many ways and are seen as a source of competitive advantage for companies (Zawislak et al. 2012). Varis and Littunen (2010) argue that the main purpose of companies' orientation towards innovation activities is to improve the performance and success of the company. The impact of innovation activities on business performance is also highlighted in the Oslo Handbook (OECD and Eurostat, 2005). Many studies focusing on the relationship between innovation and performance in the literature provide a positive assessment that high-level innovation activities cause an increase in business performance (Damanpour et al., 1989; Lawless and Fisher, 1990; Griliches and

Table 5. Structural Equation Modeling Analysis Results

\begin{tabular}{|c|c|c|c|c|c|c|c|}
\hline Hypothesis & \multicolumn{3}{|c|}{$\begin{array}{l}\text { Relationships } \\
\text { Latent Variables }\end{array}$} & $\begin{array}{l}\text { Standardized } \\
\text { Coefficients } \\
(\boldsymbol{B})\end{array}$ & $\begin{array}{l}\text { Standard } \\
\text { Error } \\
\text { (SE) }\end{array}$ & $\begin{array}{l}\text { Critical } \\
\text { Value } \\
\text { (CR) }\end{array}$ & $\begin{array}{l}\mathbf{P} \\
\text { Value }\end{array}$ \\
\hline $\mathrm{H}_{1}$ & $\begin{array}{c}\text { R\&D } \\
\text { Capability }\end{array}$ & $\rightarrow$ & $\begin{array}{c}\text { Product } \\
\text { Performance }\end{array}$ & .304 & .118 & 2.099 & .036 \\
\hline $\mathrm{H}_{2}$ & $\begin{array}{l}\text { Learning } \\
\text { Capability }\end{array}$ & $\rightarrow$ & $\begin{array}{c}\text { Product } \\
\text { Performance }\end{array}$ & -.172 & .143 & -1.103 & .270 \\
\hline Hypothesis & \multicolumn{3}{|c|}{$\begin{array}{l}\text { Relationships } \\
\text { Latent Variables }\end{array}$} & $\begin{array}{l}\text { Standardized } \\
\text { Coefficients } \\
\text { (B) }\end{array}$ & $\begin{array}{l}\text { Standard } \\
\text { Error } \\
\text { (SE) }\end{array}$ & $\begin{array}{l}\text { Critical } \\
\text { Value } \\
\text { (CR) }\end{array}$ & $\begin{array}{l}\mathbf{P} \\
\text { Value }\end{array}$ \\
\hline $\mathrm{H}_{3}$ & $\begin{array}{l}\text { Innovation } \\
\text { Capability }\end{array}$ & $\rightarrow$ & $\begin{array}{c}\text { Product } \\
\text { Performance }\end{array}$ & -.062 & .086 & -.570 & .569 \\
\hline $\mathrm{H}_{4}$ & $\begin{array}{c}\text { R\&D } \\
\text { Capability }\end{array}$ & $\rightarrow$ & $\begin{array}{c}\text { Marketing } \\
\text { Performance }\end{array}$ & -.636 & .273 & -2.156 & .031 \\
\hline $\mathrm{H}_{5}$ & $\begin{array}{l}\text { Learning } \\
\text { Capability }\end{array}$ & $\rightarrow$ & $\begin{array}{c}\text { Marketing } \\
\text { Performance }\end{array}$ & .347 & .177 & 2.047 & .041 \\
\hline $\mathrm{H}_{6}$ & $\begin{array}{l}\text { Innovation } \\
\text { Capability }\end{array}$ & $\rightarrow$ & $\begin{array}{c}\text { Marketing } \\
\text { Performance }\end{array}$ & -.259 & .171 & -1.365 & .172 \\
\hline $\mathrm{H}_{7}$ & $\begin{array}{l}\text { Marketing } \\
\text { Capability }\end{array}$ & $\rightarrow$ & $\begin{array}{c}\text { Marketing } \\
\text { Performance }\end{array}$ & 1.042 & .477 & 2.583 & .010 \\
\hline $\mathrm{H}_{8}$ & \begin{tabular}{|c|} 
Product \\
Performance
\end{tabular} & $\rightarrow$ & $\begin{array}{c}\text { Marketing } \\
\text { Performance }\end{array}$ & .109 & .056 & 2.209 & .027 \\
\hline $\mathrm{H}_{9}$ & $\begin{array}{l}\text { Strategic } \\
\text { Planning } \\
\text { Capability }\end{array}$ & $\rightarrow$ & $\begin{array}{c}\text { Marketing } \\
\text { Performance }\end{array}$ & .124 & .140 & .914 & .361 \\
\hline
\end{tabular}

Note: Those with a p-value less than 0.05 show that they have a significant effect and that the proposed hypothesis is accepted. 
Mairesse, 1990; Deshpande et al., 1993; Gao and Fu, 1996; Crepon et al., 1998; Han et al., 1998; Hult and Ketchen, 2001; Lööf and Heshmati, 2002; Guan, 2002; Calantone et al., 2002; Oke, 2007; Kafouros et al., 2008; Vega- Jurado et al., 2008; Muhammed et al., 2014; Jajja et al., 2017; Exposito and Sanchis-Llopis, 2018; Udriyah et al., 2019; Wahab et al., 2020; Hameed et al., 2021; Purwati et al., 2021).

According to the literature, technological capabilities are defined by various authors as the effective development of a new product or process, and the technical activity and business capability of a company, including other activities (Teece et al., 1997); the complete of a company's special efforts and strategies for choosing, establishing, directing understanding, developing and improving technology (Sobanke et al., 2012); as providing sustainable innovation capability and market success to companies by acquiring, harmonizing and improving knowledge and skills (Cerulli, 2014).

According to the analysis, it has been identified that R\&D capability has a significant effect on product performance and marketing performance. These results are in consistent with the similar studies in the literature (Nord, 2011; Falk, 2012; Demirel \& Mazzucato, 2012; Garcia-Manjon \& Romero-Merino, 2012; Grimpe et al., 2017; Guo et al., 2020). However, R\&D capability has a significant but negative effect on direct marketing performance. This effect turns into a positive effect through the mediating effect of product performance. In other words, although R\&D capability has a direct negative effect on marketing performance, this situation turns into a positive effect with the intermediary effect of product performance. This finding also supports the results of Stock and Reiferscheid's study published in 2014.

On the other hand, it can be stated that learning capability has a significant and positive effect on marketing performance. This result is supported by the results of similar studies in the literature (Baker \& Sinkula, 1999; Goh \& Ryan, 2002; Bontis et al., 2002; Lin et al., 2008; Migdadi, 2019; Pham \& Hoang, 2019; Hindasah \& Nuryakın, 2020). Another important finding of the study is that marketing capability has a significant and positive effect on marketing performance. This result is similar to many research results in the literature (Hooley et al., 1999; Vorhies \& Harker, 2000; Tsai \& Shih, 2004; Azizi et al., 2009; Eng \& Jones, 2009; Morgan et al., 2009a, 2009b; Ros et al., 2010; Nath et al., 2010; Ren et al., 2015; Lewandowska et al., 2016; Ferreira et al., 2018; Davcik et al., 2020; Acikdilli et al., 2020; Mehta and Ali, 2020; Novita et al., 2020). The other essential result of this study is the significant and positive effect of product performance on marketing performance. The results of similar studies in the literature also support this finding (Xin et al., 2010;
Exposito \& Sanchis-Llopis, 2018; Kristinae et al., 2020; Christa \& Kristinae, 2021).

As a consequence of the explanatory factor analysis, it was determined that marketing capability was formed as two sub-dimensions. These sub-dimensions were defined by the authors as "internal marketing capability" and "external marketing capability". This classification overlaps with some approaches regarding marketing capability. For example, Day (1994) divided marketing capabilities as the capability to define the customer needs of the business (internal) and the capability to establish a relationship with them (external). Similarly, Moller and Anttila (1987) divided marketing capabilities into two groups as external and internal capabilities.

Hamel and Prahalad (1994) emphasized that technological capabilities are one of the critical basic capabilities that create a competitive advantage for a business, especially in the phase of product development and new product creation. Similarly, customer information system development activities (Cooper, 1992) and the effects of the capabilities of production, marketing and R\&D departments on the new product development process (Zirger \& Maidique, 1990) were emphasized. On the other hand, there are also studies showing that companies with high technological capability are more successful in innovation than companies with the lower technological capability (Malerba and Marengo, 1995; Danneels, 2002; Yam et al., 2004; Ngumi, 2014; Ali et al., 2020; Zimmermann et al., 2020).

In summary, according to the findings of the research, it can be stated that there are important links between the superior technological capabilities of the companies providing sustainable competitive advantage and their performance. In consistent with the similar studies, it can be stated that there is a relation between the technological innovation capabilities of the companies located in Technoparks in Turkey and both marketing and product performances.

The main contribution of this study is that it not only explains the effects of some types of innovation on business performance but also deals with the relationship between innovation capabilities and business performance of companies in a more specific approach and it reveals the effects of technological innovation capabilities on both product and marketing performance. In addition, most of the studies in the literature mainly focus on the companies operating in limited number of sectors, in this study, companies operating in many different sectors engaged in $R \& D$ and innovation activities were evaluated.

With innovation activities, companies can get benefits such as developing products and services that can cre- 
ate different value in the market, and attracting the attention of consumers. Companies need to include innovation activities in their business processes in order to increase their performance and gain a competitive advantage in the rapidly changing competitive environment. In order to respond quickly to diverse customer demands, companies must adopt an innovative management approach. Moreover, companies should identify and improve strategies to develop these capabilities that make it easier to enter new markets, make a difference while satisfying customer demands and needs, and that is difficult to imitate by their competitors.

Technopark's management companies can diversify the technical support and consultancy services that they provide to the companies operating in their structure in order to meet the marketing needs of the companies to transform their R\&D and innovation activities into concrete products. In addition, they can increase their mentoring activities on the commercialization of intellectual and industrial property rights such as patents and designs that arise as a result of R\&D and innovation activities. According to the results of the study, it is seen that especially $R \& D$, learning and marketing capabilities affect business performance. In this context, the use of these technological innovation capabilities by the executives can positively affect their performance and bring sustainable success

Since the authors discuss only the companies operating in Technoparks located in Turkey, it could be stated that the study has a limitation in terms of generalization. Although the study covers all of the companies that are operating in the field of innovation and Research and Development in Technoparks overall Turkey, it could also be applied for other companies that perform similar activities outside Technoparks. Additionally, although there is no sectoral restriction in this study, the studies that focus on only one sector may provide different results. Moreover, comparative analysis between sectors can be made as well. On the other hand, adding different business capabilities to the model can increase the explanatoriness of the model. The effects of business capabilities on performance can also be analyzed comparatively between developing and developed countries.

\section{REFERENCES}

ACIKDILLI, G., MINTU-WIMSATT, A., KARA, A., AND SPILLAN, J. E. (2020). Export market orientation, marketing capabilities and export performance of SMEs in an emerging market: a resource-based approach. Journal of Marketing Theory and Practice, 1-16.

ACS, Z. J., AUDRETSCH, D. B., \& FELDMAN, M. P. (1992). Real effects of academic research: comment. The American Economic Review, 82(1), 363-367.

ALAM, S. S., NOR, N. G. M., ARUGUMUGAM, V., KALIAPPAN, P., FANG, L. S. (2013). Relationships Between Innovation Capabilities, Business Performance, Marketing Performance and Financial Performance: A Literature Review, Business and Management Horizons, 1(1), 59-73.

ALI, H., HAO, Y. \& AIJUAN, C. (2020). Innovation capabilities and small and medium enterprises' performance: An exploratory study. The Journal of Asian Finance, Economics, and Business, 7(10), 959-968.

ALJANABI, A. R. A. (2018). The mediating role of absorptive capacity on the relationship between entrepreneurial orientation and technological innovation capabilities. International Journal of Entrepreneurial Behavior \& Research.

ALQERSHI, N. (2021). Strategic thinking, strategic planning, strategic innovation and the performance of SMEs: The mediating role of human capital. Management Science Letters, 11(3), 1003-1012.

ARTZ, W. K., NORMAN, P. M., HATFIELD, D. E., CARDINAL, L. B. (2010). A Longitudinal Study of The Impact of R\&D, Patents and Product Innovation on Firm Performance. Journal of Product Innovation Management, 27(5), 725-740.

ASHKENAS, R., ULRICH, D., JICK, T., KERR, S. (1995). The Boundaryless Organization: Breaking the Chains of the Organizational Structure, San Francisco: Jossey-Bass.

ASHTIANIPOUR, Z., ZANDHESSAMI, H. (2015). An integrated ISM-DEMATEL model for evaluation of technological innovation capabilities' impact on the competitiveness of small \& medium-size enterprises (SMEs). In 2015 Portland International Conference on Management of Engineering and Technology (PICMET) (pp. 322-334). IEEE.

ATUAHENE-GIMA, K., (1996). Market Orientation and Innovation. Journal of Business Research, 35(2), 93103.

AZIZI, S., MOVAHED, S. A., KHAH, M. H. (2009). The Effect of Marketing Strategy and Marketing Capabilities on Business Performance. Case Study: Iran's Medical Equipment Sector. Journal of Medical Marketing, 9(4), 309-317. 
BAE, C. S. \& KIM, D. (2003). The Effect of R\&D Investments on Market Value of Firms: Evidence from the US, Germany, and Japan. The Multinational Business Review, 11(3), 51-75.

BAGOZZI, R. \& YI, Y. (1988). On the Evaluation of Structure Equation Models. Journal of the Academy of Marketing Science, 16(1), 74-94.

BAKER, E.W. \& SINKULA, J.M. (1999). The Synergistic Effect of Market Orientation and Learning Orientation on Organizational Performance. Academy of Marketing Science Journal, 27(4), 411-427.

BAL, H. (2001). Bilimsel Araştırma Yöntem ve Teknikleri", Süleyman Demirel Üniversitesi Basımevi, SDÜ Yayın No: 20, Isparta.

BARNEY, J. (1991). Firm Resources and Sustained Competitive Advantage. Journal of Management, 17(1), 99-120.

BIGLIARDI, B., (2013). The Effect of Innovation on Financial Performance: A Research Study Involving SMEs. Innovation: Organization \& Management, 15(2), ss. 245-256.

BONTIS, N., CROSSAN, M. \& HULLAND, J. (2002). "Managing an Organizational Learning System By Aligning Stocks And Flows. Journal of Management Studies, 39(4), 437-469.

CALATONE, J. R., CAVUSGIL, T. \& ZHAO, Y. (2002). Learning Orientation, Firm İnnovation Capability and Firm Performance. Industrial Marketing Management, 31(6), 515-524.

CALOGHIROU, Y., KASTELLI, I. \& TSAKANIKAS, A. (2004). Internal Capabilities and External Knowledge Sources: Complements or Substitutes for Innovative Performance. Technovation, 24 (1), 29-39.

CERULLI, G., (2014). The Impact of Technological Capabilities on Invention: An Investigation Based on Country Responsiveness Score. World Development, 59, 2014, ss.147-165.

CHAHAL, H. \& KAUR, J. (2013). Impact of marketing capabilities on competitive advantage and business performance: research propositions. International Journal of Business Competition and Growth, 3(2), 121-138.

CHEN, C.J. \& HUANG J.W. (2009). Strategic Human Resource Practices and Innovation Performance: The Mediating Role of Knowledge Management Capacity. Journal of Business Research, 62,104-114.

CHEN, M.H. \& YANG, Y.J. (2009). Typology and performance of new ventures in Taiwan. A model based on opportunity recognition and entrepreneurial creativity. International Journal of Entrepreneurial Behaviour E Research, 15(5), 398-414.

CHEN, Q., WANG, C.H. AND HUANG, S.Z. (2020).
Effects of organizational innovation and technological innovation capabilities on firm performance: evidence from firms in China's Pearl River Delta. Asia Pacific Business Review, 26(1), 72-96.

CHENG, C. C. \& KRUMWIEDE, D. (2010). The effects of market orientation and service innovation on service industry performance: an empirical study. Operational Management Research, 2010 (3), 161-171.

CHIESA, V., COUGHLAN, P. \& VOSS, C.A. (1996). Development of A Technical Innovation Audit. Journal of Product Innovation Management, 13(2), 105-136.

CHRISTA, U. \& KRISTIANE, V. (2021). The effect of product innovation on business performance during the COVID 19 pandemic. Uncertain Supply Chain Management, 9(1), 151-158

COHEN, M., W. \& LEVINTHAL, D.A., (1990). Absorptive Capacity: A New Perspective on Learning and Innovation. Administrative Science Quarterly, 35 (1), 128-152

COHEN, M.W. \& LEVINTHANL, D.A., (1989). Innovation and Learning: The Two Faces of R\&D. The Economic Journal, 99(397), 569-596.

COOPER, G. R., (1992). The Newprod System: The Industry Experience. Journal of Product Innovation Management, 9(2), ss. 113-127.

CREPON, B., DUGUET, E. \& MAIRESSE, (1998). Research, Innovation and Productivity: An Econometric Analysis at The Firm Level. Economics of Innovation and New Technology, 7(2), 115-158.

DAMANPOUR, F., SZABAT, K. A. \& EVAN, W.M. (1989). The Relationship Between Types of Innovation and Organizational Performance, Journal of Management Studies, 26(6), 587-602.

DANNEELS, E., (2002). The Dynamics of Product Innovation and Firm Competences. Strategic Management Journal, 23, 1095-1121.

DASGUPTA, S. (1985). A Local Analysis of Stability and Regularity of Stationary States in Discrete Symmetric Optimal Capital Accumulation Models. Journal of Economic Theory, 36 (2), 302-318.

DAVCIK, N.S., CARDINALI, S., SHARMA, \& CEDROLA, E. (2020). Exploring the role of international R\&D activities in the impact of technological and marketing capabilities on SMEs' performance. Journal of Business Research.

DAY, S. G. (1994). The Capabilities of Market-Driven Organizations. Journal of Marketing, 58(4), 37-52.

DEL MONTEA, A. \& PAPAGNI, E. (2003). R\&D and the Growth of Firms: Empirical Analysis of a Panel of Italian Firms. Research Policy, 32(6), 1003-1014.

DEMIREL, P. \& MAZZUCATO, M. (2012). Innovation 
and Firm Growth: Is R\&D worth it?, Industry \& Innovation, 19(1), 45-62.

DESHPANDE, R., FARLEY, J. U. \& WEBSTER, J.R. (1993). Corporate Culture, Customer Orientation, and Innovativeness in Japanese Firms: A Quadrad Analysis. Journal of Marketing, 57(1), 23-37.

DIERIKX, I. \& COOL, K. (1989). Asset Stock Accumulation and The Sustainability Of Competitive Advantage: REPLY. Management Science, 35(12).

EGE, İ. \& ŞENER, Z. (2013). Performans Ölçümünde Kullanılan Yöntemler: Performans Karnesi ve Kumanda Paneli Karşılaştırması. Muhasebe ve Finansman Dergisi, 57, 107-120.

EHIE, C. I. \& OLIBE, K. O. (2010). The Effect of R\&D Investment on Firm Value: An Examination of US Manufacturing and Service Industries. International Journal of Production Economics, 128(1), 127-135.

ELMQUIST, M. \& LE MASSON, P. (2009). The value of a failed R\&D project: an emerging evaluation framework for building innovative capabilities. $R \mathcal{E} D$ Management, 39(2), 136-152.

ENG, T.Y. \& SPICKETT-JONES, J. G. (2009). An Investigation of Marketing Capabilities and Upgrading Performance. Journal of World Business, 44(4), 463-475.

ERDEM B., GÖKDENIZ A. \& MET, Ö. (2011). Yenilikçilik ve İşletme Performansı İlişkisi: Antalya'da Etkinlik Gösteren 5 Yıldızlı Otel İşletmeleri Örneği. Dokuz Eylül Üniversitesi İktisadi ve İdari Bilimler Fakültesi Dergisi, 26(2), 77-112.

EXPOSITO, A. \& SANCHIS-LLOPIS, J.A. (2018). Innovation and business performance for Spanish SMEs: New evidence from a multi-dimensional approach. International Small Business Journal, 36(8), 911-931.

FALK, M. (2012). Quantile Estimates of the Impact of R\&D Intensity on Firm Performance. Small Business Economics, 39(1), ss. 19-37.

FANG, E. E. \& ZOU, S. (2009). Antecedents and Consequences of Marketing Dynamic Capabilities in International Joint Ventures. Journal of International Business Studies, 40(5), 742-761.

FERREIRA, J., CARDIM, S. \& BRANCO, F. (2018). Dynamic capabilities, marketing and innovation capabilities and their impact on competitive advantage and firm performance. In 2018 13th Iberian Conference on Information Systems and Technologies (CISTI) (pp. 1-7). IEEE.

FORNELL, C. \& LARCKER, D.F. (1981). Evaluating Structural Equation Models with Unobservable Variables and Measurement Error. Journal of Marketing Research, 18(1), 39-50.

FORSMAN, H. (2011). Innovation Capacity and In- novation Development in Small Enterprises. A Comparison Between the Manufacturing And Service Sectors. Research policy, 40(5), 739-750.

GARCIA-MANJONA, J. \& REMORA-MERINO, M. E. (2012). Research, Development and Firm Growth: Empirical Evidence from European Top R\&D Spending Firms. Research Policy, 41(6), ss. 1084-1092.

GARVIN, A.D. (1993) Building a Learning Organization, Harvard Business Review, July-August, 78-91.

GATIGNON, H. \& XUEREB, J.M. (1997). Strategic Orientation of The Firm and New Product Performance. Journal of Marketing Research, 34(1), 77-79.

GOH, S. \& PETER, R. (2002) Learning Capability, Organization Factors and Firm Performance. Third European Conference on Organizational Knowledge, Learning and Capabilities.

GOMES, G. \& WOJAHN, R. M. (2017). Organizational Learning Capability, Innovation and Performance: Study in Small And Medium-Sized Enterprises (SMEs). Revista de Administração (São Paulo), 52(2), 163175.

GÖK, O. \& PEKER, S. (2017). Understanding The Links Among Innovation Performance, Market Performance and Financial Performance. Review of Managerial Science, 11(3), 1-27.

GRILICHES, Z. (1981). Market Value, R\&D and Patents. Economic Letters, 7(2), 183-187.

GRIMPE, C., SOFKA, W., BHARGAVA, W. \& CHATTERJEE, R. (2017). R\&D, marketing innovation, and New Product Performance: A Mixed-Methods Study. Journal of Product Innovation Management, 34(3), 360-383.

GUAN, J. C., YAM, R.C.M., MOK, C.K. \& MA N., (2006). A Study of The Relationship Between Competitiveness And Technological Innovation Capability Based on DEA Models. European Journal of Operational Research, 170(3), 971-986.

GUAN, J.N. \& M.A., (2003), Innovative Capability and Export Performance of Chinese Firms. Technovation, 23(9), 737-747.

GUAN, J. (2002) Comparison Study on Industrial Innovation between China and Some European Countries. Production and Inventory Management Journal, 43(3), 2002, 30-46.

GUO, C., SARKAR, S., ZHU, J. \& WANG, Y. J. (2020). R\&D investment, business performance, and moderating role of Guanxi: Evidence from China. Industrial Marketing Management, 91, 55-63.

GUO, B., WANG, J. \& WEI, S.X. (2018). R\&D spending, strategic position and firm performance. Frontiers of Business Research in China, 12(1), 1-19. 
HAIR, J.F., BLACK, W.C., BABIN, B. J. \& ANDERSON, R.E. (2014). Multivariate Data Analysis. Pearson New International Edition, Always Learning.

HAMEED, W. U., NISAR, Q. A. \& WU, H. C. (2021). Relationships between external knowledge, internal innovation, firms' open innovation performance, service innovation and business performance in the Pakistani hotel industry. International Journal of Hospitality Management, 92, 102745.

HAMEL, G. \& PRAHALAD, C. K. (1994). Competing for the future. Harvard Business Review, 72(4), 122-128.

HAN, K. J., KIM, N. \& SRIVASTAVA, R. K. (1998). Market Orientation and Organizational Performance: Is Innovation a Missing Link? Journal of Marketing, 62(4), 30-45.

HAXTON, B. M. \& MEADE, F. (2009). 21st Century Vision: Developing a Global Sustainable Science and Technology Park Strategy and Creating Economic Development. International Institute for Sustainable Laboratories, 110

HIGGINS, M. J. (1995). Innovation: The Core Competence. Strategy \& Leadership, 23 (6), 32-36.

HINDASAH, L. \& NURYAKIN, N. (2020). The relationship between organizational capability, organizational learning and financial performance. The Journal of Asian Finance, Economics, and Business, 7(8), 625-633.

HOOLEY, J. G., GREENLEY, G. E., CADOGAN, J. W \& FAHY, J. (2005) The Performance Impact of Marketing Resources. Journal of Business Research, 58 (1), $18-27$.

HOOLEY, G., FAHY, J., COX, T., BERACS, J., FONFORA, K. \& SNOJ, B., (1999). Marketing Capabilities and Firm Performance: A Hierarchical Model. Journal of Market Focused Management, 4(3), 259-278.

HOPENHAYN, A. H., (1992). Entry, Exit, and Firm Dynamics in Long Run Equilibrium. Econometrica, 60(5), 1127-1150.

HULL, C. E. \& COVIN, J. G. (2010). Learning Capability, Technological Parity, and Innovation Mode Use. Journal of Product Innovation Management, 27(1), 97-114

HULT, G. T., HURLEY, R. F. \& KNIGHT, G. A. (2004). Innovativeness: Its Antecedents and Impacts on Business Performance. Industrial Marketing Management, 33(5), 429-438.

JAAKKOLA, M., MOLLER, K., PARVINEN, P., EVANSCHITZKY, H. \& MUHLBACHER, H. (2010). Strategic marketing and business performance: A study in three European 'engineering countries'. Industrial Marketing Management, 39(8), 1300-1310.

JAFFE B. A. (1989). Real Effects of Academic Research. American Economic Review, 79 (5), 957-970.
JAJJA, M. S. S., KANNAN, V. R., BRAH, S. A., \& HASSAN, S. Z. (2017). Linkages between firm innovation strategy, suppliers, product innovation, and business performance. International Journal of Operations \& Production Management.

JIMENEZ-JIMENEZ D. \& RAQUEL SANZ-VALLE (2011). Innovation, Organizational Learning and Performance. Journal of Business Research, 64 (4), 408-417.

KAFOUROS I. M., BUCKLEY, P.J., SHARP, J.A. \& CHENGQI Wang (2008). The Role of Internationalization in Explaining Innovation Performance. Technovation, 28 (1-2), 63-74.

KARAMAN R. (2009). İşletmelerde Performans Ölçümünün Önemi ve Modern Bir Performans Ölçme Aracı Olarak Balanced Scorecard. Selçuk Üniversitesi İ̈BF Sosyal ve Ekonomik Araştırmalar Dergisi, 8 (16), 410427.

KARACAER S., AYGÜN, M. \& İÇ SÜLEYMAN (2009). Araştırma ve Geliştirme Giderlerinin Firma Performansı Üzerindeki Etkisi: İstanbul Menkul Kiymetler Borsası Üzerine Bir İnceleme. World of Accounting Science, 11 (2), 65-86.

KRASNIKOV A. \& JAYACHANDRAN, S. (2008). The Relative Impact of Marketing, Research-and-Development and Operations Capabilities on Firm Performance. Journal of Marketing, 72(4), 1-11.

LAU K.W. A., YAM, R.C.M. \& TANG, E.P.Y. (2010). The Impact of Technological Innovation Capabilities on Innovation Performance: An Empirical Study in Hong Kong. Journal of Science and Technology Policy in China, 1 (2) 163-186.

LAWLESS W. M. \& FISHER, R.J. (1990). Sources of Durable Competitive Advantage in New Products. Journal of Product Innovation Management, 7(1), 35-44.

LAWSON B. \& SAMSON, D. (2001). Developing Innovation Capability in Organisations: A Dynamic Capabilities Approach. International Journal of Innovation Management, 5(3), 377-400.

LEE M. SANG, DAVID L. OLSON, SILVANA TRIMI (2012). Co-Innovation: Convergenomics, Collaboration and Cocreation for Organizational Values. Management Decision, 50(5), 817-831.

LEWANDOWSKA, M. S., SZYMURA-TYC, M., GOEĘBIOWSKI, T. (2016). Innovation complementarity, cooperation partners, and new product export: Evidence from Poland. Journal of Business Research, 69(9), 3673-3681.

LI T. \& CALANTONE, R.J. (1998). The Impact of Market Knowledge Competence on New Product Advantage: Conceptualization and Empirical Examination. Journal of Marketing, 62(4), 13-29.

LIN, C. H., PENG, C. H., \& KAO, D. T. (2008). The 
innovativeness effect of market orientation and learning orientation on business performance. International journal of manpower.

LÖÖF H. \& HESHMATI, A. (2002). Knowledge Capital and Performance Heterogeneity: A Firm Level Innovation Study. International Journal of Production Economics, 76 (1), 61-85.

MAIDIQUE A. M. \& ZIRGER, B.J. (1984). A Study of Success and Failure in Product Innovation: The Case of the U.S. Electronics Industry. IEEE Transactions in Engineering Management, 31 (4), 192-203.

MALERBA, F. \& MARENGO, L. (1995). Competence, Innovative Activities and Economic Performance in Italian High-Technology Firms. International Journal of Technology Management, 10(4-6), 461-477.

MCKELVIE, A., \& DAVIDSSON, P. (2009). From resource base to dynamic capabilities: an investigation of new firms. British Journal of Management, 20, S63-S80.

MCMILLAN, C.S., MAURI, A. \& HAMILTON, R.D. III (2003). The Impact of Publishing and Patenting Activities on New Product Development and Firm Performance: The Case of the US Pharmaceutical Industry. International Journal of Innovation Management 7(2):213-221.

MEHTA, A. M., ALI, F. H., FAROOQ, S. \& TARIQ, M. (2020). Dynamic Managerial Capabilities, Competitive Advantage and Business Performance: An Integrative Model, Literature Review and Research Propositions. Academy of Strategic Management Journal, 19(4).

MERRILEES B., RUNDLE-THIELE, S. \& LYE, A. (2011). Marketing Capabilities: Antecedents and Implications for B2B SME Performance. Industrial Marketing Management, 40(3), 368-375.

MIGDADI, M.M. (2019). Organizational learning capability, innovation and organizational performance. European Journal of Innovation Management.

MOLLER K. \& ANTTILA, M. (1987). Marketing Capability A Key Success Factor in Small Business?. Journal of Marketing Management, 3(2), 185-203.

MORGAN A. N. (2009a). Linking Marketing Capabilities With Profit Growth. International Journal of Research in Marketing, 26(4), 284-293.

MORGAN A. N. \& VORHIES, D.W. (2009b). Market Orientation, Marketing Capabilities and Firm Performance. Strategic Management Journal, 30(8), 909-920

MOEN, O, TVEDTEN, T. \& WOLD, A., (2018). Exploring the relationship between competition and innovation in Norwegian SMEs. Cogent Business \& Management, 5(1), 1564167.

MURRAY, J. Y., GAO, G. Y. \& KOTABE, M. (2011). Market orientation and performance of export ven- tures: the process through marketing capabilities and competitive advantages. Journal of The Academy of Marketing Science, 39(2), 252-269.

MUTHONI, B. (2017). Effects of innovation on competitive advantage in fast moving consumer goods, a case of pz sussons East Africa ltd., MBA Thesis, United States International University-Africa, 72p.

NASSIMBENI G. (2001). Technology, innovation capacity, and the export attitude of small manufacturing firms: a logit/to bit model. Research Policy, 30(2), 245262.

NGUMI, P. M. (2014). Effect of bank innovations on financial performance of commercial banks in Kenya (Doctoral dissertation).

NURJAYA, N., AFFANDI, A., ERLANGGA, H., SUNARSI, D. \& JASMANI, J. (2021). The Effect of Product Promotion and Innovation Activities on Marketing Performance in Middle Small Micro Enterprises in Cianjur. Budapest International Research and Critics Institute (BIRCI-Journal): Humanities and Social Sciences, 4(1), 528-540.

OECD ve Eurostat (2006). "Oslo Kilavuzu: Yenilik Verilerinin Toplanması ve Yorumlanması için İlkeler", 3. Baskı, (Çev: TUBİTAK), Ankara.

OJHA, D., PATEL, P. C., \& SRIDHARAN, S. V. (2020). Dynamic strategic planning and firm competitive performance: A conceptualization and an empirical test. International Journal of Production Economics, 222, 107509.

PANDA, H. \& RAMANATHAN, K. (1996). Technological capability assessment of a firm in the electricity sector. Technovation, 16(10), 561-588.

PURWATI, A., BUDIYANTO, B., SUHERMIN, S., \& HAMZAH, M. (2021). The effect of innovation capability on business performance: The role of social capital and entrepreneurial leadership on SMEs in Indonesia. Accounting, 7(2), 323-330.

RAMASWAMI, S. N., SRIVASTAVA, R. K., \& BHARGAVA, M. (2009). Market-based capabilities and financial performance of firms: insights into marketing's contribution to firm value. Journal of the Academy of Marketing Science, 37(2), 97-116.

REN, S., EISINGERICH, A. B., \& TSAI, H. T. (2015). How do marketing, research and development capabilities, and degree of internationalization synergistically affect the innovation performance of small and medium-sized enterprises (SMEs)? A panel data study of Chinese SMEs. International Business Review, 24(4), 642-651.

RIBAU, C. P., MOREIRA, A. C., \& RAPOSO, M. (2017). SMEs innovation capabilities and export performance: an entrepreneurial orientation view. Journal of Business 
Economics and Management, 18(5), 920-934.

ROMIJN H. \& MANUEL A. (2002). Determinants of Innovation Capability in Small Electronics and Software Firms in Southeast England. Research Policy, 31 (7), 10531067.

CRUZ-ROS, S., CRUZ, T. F. G. \& PEREZ-CABANERO, C. (2010). Marketing capabilities, stakeholders' satisfaction, and performance. Service Business, 4(3-4), 209-223.

ROTHWELL, R. (1992). Successful industrial innovation: critical factors for the 1990s. REd Management, 22(3), 221-240.

Shan, J., \& Jolly, D. R. (2010). Accumulation of technological innovation capability and competitive performance in Chinese firms: A quantitative study. IAMOT 8-11.

SHER P. J. \& YANG., P.Y. (2005). The effects of innovative capabilities and R\&D clustering on firm performance: the evidence of Taiwan's semiconductor industry. Technovation, 25(1), 33-43.

SOBANKE O. V., ILORI, M.O. \& ADEGBITE, S.A. (2012). Technological Capability in Metal Fabricating Firms in Southwestern Nigeria. American Journal of Industrial and Business Management, 2(4), 176-183.

SONG M., DI BENEDETTO, A. \& NASON, R.W. (2007). Capabilities and Financial Performance: The Moderating Effect of Strategic Type. Journal of the Academic Marketing Science, 35(1), 18-34.

STOCK M. R. \& REIFERSCHEID, I. (2014). Who Should Be in Power to Encourage Product Program Innovativeness, R\&D or Marketing?. Journal of the Academic Marketing Science, 42 (14), 264-276.

SWAN A. J. \& NEWELL. S. (1995). The Role of Professional Associations in Technology Diffusion. Organization Studies, 16 (5), 847-874.

TABACHNICK B. G. \& FIDELL, L.S. (2007). Using Multivariate Statistics. Allyn \& Bacon/Pearson Education.

TATAR H. (2010). İnovasyonun Finansal Performans Üzerindeki Etkisi: İmalat Sektöründe Bir Uygulama, (Yüksek Lisans Tezi), Gaziantep Üniversitesi.

TEECE J. D., PISANO, G. \& SHUEN, A. (1997). Dynamic Capabilities and Strategic Management. Strategic Management Journal, 18(7), 509-533.

TEECE J. D., RUMELT, R. G. DOSI \& WINTER, S. (1994). Understanding Corporate Coherence. Journal of Economic Behavior and Organization, 2 (1), 1-30.

TROTT, P. (2002). Innovation Management and New Product Development, London: Prentice Hall.

TROTT P., Tom Maddocks \& Colin Wheeler. (2009). Core Competencies for Diversifying: Case Study of a Small Business. Strategic Change, 18 (1-2) 27-43.
TSAI MING-TIEN \& SHIH CHIA-MEI (2004). The Impact of Marketing Knowledge Among Managers on Marketing Capabilities and Business Performance. International Journal of Management, 21(4), 524-530.

UDRIYAH, U., THAM, J., \& AZAM, S. (2019). The effects of market orientation and innovation on competitive advantage and business performance of textile SMEs. Management Science Letters, 9(9), 1419-1428.

VACCARO A., RONALDO P. \& FRANCISCO M. V. (2010). Knowledge Management Tools, Inter-Organizational Relationships, Innovation and Firm Performance. Technological Forecasting and Social Change, 77(7), 10761089.

VANDERPAL, G. (2015). Impact of R\&D expenses and corporate financial performance. Journal of Accounting and Finance, 15(7), 135-149.

VARIS MIIKA, Hannu Littunen (2010). Types of Innovation, Sources of Information and Performance in Entreprenurial SMEs. European Journal of Innovation Management, 13(2), 128-154.

VEGA-JURADO JAIDER, ANTONIO GUTIERREZ-GRACIA, IGNACIO FERNANDEZ-DELUCIO, LINEY MANJARRES-HENRIQUEZ. (2008). “The Effect of External and Internal Factors on Firm's Product Innovation. Research Policy, 37(4), 616-632.

VORHIES W. DOUGLAS. (1998). An Investigation of the Factors Leading to the Development of Marketing Capabilities and Organizational Effectiveness. Journal of Strategic Marketing, 6(1), 3-23.

VORHIES W. DOUGLAS, MICHAEL HARKER. (2000). The Capabilities and Performance Advantages of Market-Driven Firms: An Empirical Investigation. Australian Journal of Management, 25(2), 145-171.

WANG CHAO-HUNG \& LI-CHANG HSU (2014). Building Exploration and Exploitation in the High-Tech Industry: The Role of Relationship Learning. Technological Forecasting and Social Change, 81, 331-340.

WANG, C. H., LU, I. Y., \& CHEN, C. B. (2008). Evaluating firm technological innovation capability under uncertainty. Technovation, 28(6), 349-363.

WANG, W. \& ZHANG, C. (2018). Evaluation of relative technological innovation capability: Model and case study for China's coal mine. Resources Policy, 58, 144149.

WEERAWARDENA JAY (2003). The Role of Marketing Capability in Innovation-Based Competitive Strategy". Journal of Strategic Marketing, 11(1), 15-35.

WERNERFELT BIRGER (1984). A Resource-Based View of the Firm. Strategic Management Journal, 5(2), 171-180.

XIN Y. JENNY, ANDY C.L. YEUNG, TAI C.E. CHENG (2010). “First to Market: Is Technological Innovation in 
New Product Development Profitable in Health Care Industries?", International Journal of Production Economics, 127(1), 129-135.

YAM C.M. RICHARD, JIAN CHENG GUAN, KIT FAI PUN, ESTHER P.Y. TANG (2004). An Audit of Technological Innovation Capabilities in Chinese Firms: Some Empirical Findings in Beijing, China. Research Policy, 33(8), 1123-1140.

YAO, J., CRUPI, A., DI MININ, A., \& ZHANG, X. (2020). Knowledge sharing and technological innovation capabilities of Chinese software SMEs. Journal of Knowledge Management.

YEUNG K. ARTHUR, DAVID O. ULRICH, STEPHEN W. NASON, MARY ANN VON GLINOW. (1999). Organizational Learning Capability, New York: Oxford University Press, 1999.

YU, C., ZHANG, Z., LIN, C., \& WU, Y. J. (2017). Knowledge creation process and sustainable competitive advantage: The role of technological innovation capabilities. Sustainability, 9(12), 2280.

ZASTEMPOWSKI, M., GLABISZEWSKI, W., KRUKOWSKI, K., \& CYFERT, S. (2020). Technological innovation capabilities of small and medium-sized enterprises. European Research Studies, 23(3), 460-474.

ZAWISLAK A. PAULO, ANDRE C. ALVES, JORGE TELLO-GAMARRA, FERNANDA REICHERT (2012). Innovation Capability: From Technology Development to Transaction Capability. Journal of Technology Management and Innovation, 7 (2), 14-26.

ZHANG, Y., KHAN, U., LEE, S., \& SALIK, M. (2019). The influence of management innovation and technological innovation on organization performance. a mediating role of sustainability. Sustainability, 11(2), 495.

ZHAO HONGXIN, XUESONG TONG, POH KAM WONG, JISHAN ZHU (2005). Types of Technology Sourcing and Innovative Capability: An Exploratory Study of Singapore Manufacturing Firms. Journal of High Technology Management Research, 16 (2), 209-224.

ZIMMERMANN, R., FERREIRA, L. M. D., \& MOREIRA, A. C. (2020). How supply chain strategies moderate the relationship between innovation capabilities and business performance. Journal of Purchasing and Supply Management, 26(5), 100658.

ZIRGER B. JO, MODESTO A. MAIDIQUE (1990). A Model of New Product Development: An Empirical Test. Management Science, 36(7), 867-883. 